\title{
KADAR KLORIN PADA MIE SOHUN DI PASAR KEMANTRAN KABUPATEN TEGAL TAHUN 2018
}

\author{
Wahyu Nusantara Putri ${ }^{1)}$, Tri Marthy Mulyasari ${ }^{2)}$ \\ Jurusan Kesehatan Lingkungan, Politeknik Kesehatan Kemenkes Semarang, \\ Jl. Raya Baturraden KM. 12 Purwokerto, Indonesia
}

\begin{abstract}
Abstrak
Sohun merupakan suatu produk bahan makanan kering yang dibuat dari pati dengan bentuk khas. Pada proses pembuatan sohun menggunakan klorin sebagai bahan pemutih dan masih terdapat sisa kaporit. Efek klorin dalam jangka pendek menyebabkan penyakit maag dan dalam jangka panjang mengakibatkan penyakit kanker hati dan ginjal. Tujuan dari penelitian ini adalah mengetahui kadar klorin pada mie sohun di Pasar Kemantran Kabupaten Tegal. Metode penelitian yang digunakan dengan pendekatan deskriptif yang bertujuan untuk mengukur kadar klorin pada mie sohun di Pasar Kemantran Kabupaten Tegal dan untuk mengetahui tingkat pengetahuan pedagang mie sohun dengan jumlah sampel sebanyak 5 pedagang mie sohun. Hasil pemeriksaan kadar klorin pada sampel didapatkan 2 sampel mie sohun positif menggunakan klorin yaitu sampel sohun B dengan kadar klorin 0,1 mg/L dan sampel sohun C dengan kadar klorin 0,2 mg/L sedangkan 3 sampel lainnya yaitu sampel sohun A, D, dan E menunjukkan hasil negatif menggunakan klorin. Dan tingkat pengetahuan pedagang mie sohun di Pasar Kemantran Kabupaten Tegal masih buruk. Simpulan penelitian menunjukkan 2 sampel mie sohun yang diperiksa positif menggunakan klorin dan 3 sampel mie sohun yang diperiksa negatif menggunakan klorin. Saran kerja sama dengan Dinas Kesehatan Kabupaten Tegal untuk meningkatkan pengawasan terhadap penggunaan Bahan Tambahan Pangan (BTP) khususnya pada industriindustri makanan dan melakukan pengarahan ataupun penyuluhan terhadap pedagang yang ada di Pasar Kemantran Kabupaten Tegal tentang Bahan Tambahan Pangan (BTP) yang di perbolehkan maupun tidak di perbolehkan oleh pemerintah.
\end{abstract}

Kata Kunci : Klorin, Sohun, Pasar

Abstract

Levels Of Clhorine In Sohun Noodle In The Kemantran Traditional Market Tegal Regency Year Of 2018. Sohun is a dry food product made from starch with a distinctive shape. In the process of making sohun using chlorine as a bleach agent and there are still chlorine remaining. The effects of chlorine in the short term cause ulcer disease and in the long term lead to liver and kidney cancer. The purpose of this research is to know the chlorine level in sohun noodle in Kemantran Traditional Market of Tegal Regency. The research method used with descriptive approach that aims to measure chlorine levels in sohun noodle in the Kemantran Traditional Market of Tegal Regency and to know the level of knowledge of sohun noodle traders with the number of samples of 5 traders of sohun noodle. The result of chlorine content in samples obtained 2 sohun noodles samples of positive using chlorine is sample B with chlorine level of $0.1 \mathrm{mg} / \mathrm{L}$ and sample C with chlorine level of $0.2 \mathrm{mg} / \mathrm{L}$ while the other 3 samples, were samples of sohun noodles $A, D$ and $E$ showed negative results using chlorine. And the knowledge level of sohun noodles traders in Kemantran Traditional Market of Tegal Regency is still bad. The research conclusion showed 2 samples of sohun noodles tested positive using chlorine and 3 samples of sohun noodles that were examined negatively using chlorine. Suggestions in cooperation with Tegal District Health Office to increase supervision on the use of Food Added Substances (BTP), especially in food industries and conduct guidance or counseling to existing traders in Kemantran Traditional Market of Tegal Regency about Food Added Substances (BTP) which allowed or not allowed by the government.

Keywords $\quad$ : Clhorine, Sohun, Market

\section{PENDAHULUAN}

Undang - Undang Nomor 23 tahun 1992 tentang Kesehatan Pasal 21 (Pengamanan Makanan dan minuman) menyebutkan bahwa pengamanan makanan dan minuman diselenggarakan untuk melindungi masyarakat dari melindungi masyarakat dari makanan dan minuman yang tidak memenuhi ketentuan mengenai standar dan atau persyaratan kesehatan. Sehingga perlu diadakan upaya pencegahan dan penanggulangan yang dilakukan untuk menekan terjadinya kasus-kasus penyakit karena makanan atau keracunan makanan. Salah satu bentuk upaya tersebut ialah dengan cara mengadakan pengamatan atau pemeriksaan terhadap makanan dan bahan makanan atau minuman yang (akan) dikonsumsi

\footnotetext{
1) Email : wahyunusantarap@gmail.com

${ }^{2)}$ Email : trimarthymulyasari@gmail.com
} 
oleh masyarakat. Pemeriksaan tersebut selain dapat menilai layak tidaknya suatu makanan atau bahan makanan untuk dikonsumsi, juga sekaligus dapat menilai memadai-tidaknya proses pengelolaan makanan atau bahan makanan tersebut(Ditjen PPM \& PLP, 1990, H 1).

Peraturan pemerintah nomor 28 tahun 2004 tentang keamanan, mutu, dan gizi pangan pada bab 1 pasal 1 menyebutkan, yang dimaksud dengan bahan tambahan pangan merupakan bahan yang ditambahkan ke dalam makanan untuk mempengaruhi sifat atau bentuk pangan atau produk pangan. Kualitas bahan makanan di tentukan antara lain oleh cita rasa,warna,tekstur dan nilai gizi. Akan tetapi, sebagian besar konsumen sebelum mempertimbangkan cita rasa dan nilai gizi, akan lebih tertarik pada tampilan atau warna makanan (Cahyo Saparinto dan Diana Hidayanti, 2006).

Peraturan Menteri Kesehatan RI No. 33 Tahun 2012 tentang Bahan Tambahan Pangan (BTP) dimana peraturan tersebut tidak menyatakan bahwa klorin termasuk dalam Bahan Tambahan Pangan Kimia yang diperbolehkan untuk makanan. Menurut Adiwisastra (1989) menyebutkan bahwa salah satu penggunaan Bahan Tambahan Makanan (BTM) yang dilarang adalah klorin $\left(\mathrm{Cl}_{2}\right)$. Klorin adalah bahan kimia yang biasanya digunakan sebagai desinfektan, pemutih kertas dan proses tekstil. Efek klorin dalam jangka pendek menyebabkan penyakit maag dan dalam jangka panjang mengakibatkan penyakit kanker hati dan ginjal.

Sohun merupakan suatu produk bahan makanan kering yang dibuat dari pati dengan bentuk khas (SNI 01-3723-1995). Berbagai macam pati sebagai bahan baku sohun dapat berasal dari umbi-umbian, kacang hijau, jagung, ubi jalar (sweet potato), sagu, aren, midro/ganyong (canna eduliker) dan tapioka. Di Indonesia umumnya sohun dibuat dari bahan dasar pati sagu atau aren dan midro sebagai campuran.

Berdasarkan hasil penelitian sebelumnya yang dilakukan oleh Farah Tifani pada tahun 2013 tentang Studi Hygiene Sanitasi Makanan Industri Sohun PT. Naga Sakti Kecamatan Sumbang Kabupaten Banyumas menunjukkan hasil bahwa personal hygiene penjamah kurang memenuhi syarat, secara umum pengelolaan sohun sudah memenuhi syarat tetapi pada proses pembuatan sohun menggunakan klorin sebagai bahan pemutih dan masih terdapat sisa kaporit, sehingga kualitas makanan secara kimia tidak memenuhi syarat.

Pasar Kemantran Kabupaten Tegal yang tepatnya berada di Kecamatan Kramat merupakan salah satu pasar yang cukup besar dan lengkap dalam menyediakan pasokan barang yang dijual. Dengan survei pendahuluan yang telah peniliti lakukan sebelumnya, di Pasar Kemantran sendiri terdapat pedagang mie sohun yang berjumlah banyak dan sebagian besar pedagang masih menjual bebas mie sohun tanpa mengerti kandungan apa saja yang digunakan dalam pembuatan mie sohun karena pedagang hanya menjual dari produsen tanpa mengetahui proses pembuatan sohun dan biasanya pedagang mie sohun tidak hanya menjual mie sohun tapi juga menjual sembako lainnya, sehingga pedagang tidak terlalu memperhatikan hal tersebut karena barang dagang yang diperjual belikan selain mie sohun cukup beragam. Selain itu, peneliti juga menemukan indikasi bahwa ada mie sohun yang menggunakan klorin dengan melihat kondisi fisik warna dari mie sohun yang putih bersih, hal tersebut berbeda dengan kondisi fisik warna dari mie sohun yang benar adalah putih kusam transparan.

\section{BAHAN DAN METODE}

Penelitian ini termasuk dalam penelitian deskriptif yang bertujuan untuk mengetahui kondisi fisik mie sohun yang menggunakan klorin dan mengetahui kadar klorin pada mie sohun yang dijual di Pasar Kemantran Kabupaten Tegal. Subjek penelitian ini adalah kadar klorin pada mie sohun yang dijual oleh 5 pedagang di Pasar Kemantran Kabupaten Tegal. Data hasil penelitian diolah dan disusun dalam bentuk tabel dan dianalisis secara deskriptif.

\section{HASIL DAN PEMBAHASAN DATA UMUM}

Pasar Kemantran Kabupaten Tegal merupakan pasar tradisional yang terletak di Jalan Garuda, Desa Kemantran Kecamatan Kramat Kabupaten Tegal yang memliki luas $4860 \mathrm{~m}^{2}$. Jumlah pedagang yang menempati Pasar Kemantran Kabupaten Tegal sejumlah 772. Pedagang yang menempati los terdapat 554 orang sedangkan yang tidak menempati los terdapat 122 orang. Jumlah kios yang berada di Pasar Kemantran 96 buah dengan luas kios 15-20 m².

Jumlah pegawai yang ditugaskan dalam mengelola Pasar Kemantran Kabupaten Tegal berjumlah 8 orang, yang terdiri dari 1 ketua pasar dan 7 staff pelaksana. Fasilitas yang dimiliki berupa kios, los, wc umum, kantor administrasi, pos keamanan, mushola, dan TPS. Pedagang mie sohun di Pasar Kemantran Kabupaten Tegal umumnya buka dari jam 06.00 pagi sampai jam 13.00 WIB. Pada umumnya pedagang mie sohun juga berjualan bahan sembako lainnya seperti beras, minyak, kecap, telur, dan kebutuhan rumah tangga lainnya. Di Pasar Kemantran Kabupaten Tegal ini terdapat 56 pedagang sembako yang tidak semuanya menyediakan mie sohun dalam barang dagangannya. Pedagang memperoleh mie sohun tersebut dengan cara mengambil dari distributor. 
DATA KHUSUS

1. Uji Organoleptik Mie Sohun yang dijual di Pasar Kemantran Kabupaten Tegal

\begin{tabular}{|c|c|c|c|c|}
\hline \multirow[t]{2}{*}{ No. } & \multirow{2}{*}{$\begin{array}{c}\text { Kode } \\
\text { Sampel }\end{array}$} & \multicolumn{3}{|c|}{ Warna (Putih Mengkilap) } \\
\hline & & $\begin{array}{c}\text { Panelis } \\
1\end{array}$ & $\begin{array}{c}\text { Panelis } \\
2\end{array}$ & $\begin{array}{c}\text { Panelis } \\
3\end{array}$ \\
\hline 1. & $\begin{array}{c}\text { Sohun } \\
\text { Sampel } \\
\text { A }\end{array}$ & Tidak & Tidak & Tidak \\
\hline 2. & $\begin{array}{c}\text { Sohun } \\
\text { Sampel } \\
\text { B }\end{array}$ & $\mathrm{Ya}$ & Ya & $\mathrm{Ya}$ \\
\hline 3. & $\begin{array}{c}\text { Sohun } \\
\text { Sampel } \\
\text { C }\end{array}$ & $\mathrm{Ya}$ & Ya & $\mathrm{Ya}$ \\
\hline 4. & $\begin{array}{c}\text { Sohun } \\
\text { Sampel } \\
\text { D }\end{array}$ & Tidak & Tidak & Tidak \\
\hline 5. & $\begin{array}{c}\text { Sohun } \\
\text { Sampel } \\
\text { E }\end{array}$ & Tidak & Tidak & Tidak \\
\hline
\end{tabular}

Pengamatan yang dilakukan hanya meneliti 1 parameter yaitu warna, dengan hasil kriteria warna mie sohun pada 2 sampel berwarna putih mengkilap dan 3 sampel lainnya berwarna putih kusam. Warna putih mengkilap dan lebih bersih biasanya mengindikasikan bahwa sampel tersebut ada kemungkinan menggunakan klorin.

Ketiga panelis memiliki hasil yang sama dengan prensentase sebagai berikut 2 sampel (40\%) mie sohun terindikasi menggunakan klorin dan 3 sampel (60\%) mie sohun tidak terindikasi menggunakan klorin. Penggunaan pewarna makanan dan minuman yang aman telah diatur oleh Pemerintah. Hal ini dibuat dengan tujuan agar bahan makanan yang beredar terutama pewarna makanan yang digunakan memenuhi persyaratan mutu kesehatan.

Mie Sohun merupakan salah satu makanan rakyat yang bisa didapat dengan mudah di Pasar Kemantran Kabupaten Tegal, ada berbagai macam mie sohun yang diperjual belikan dan setiap sohun juga memiliki karakteristik \& mutu yang berbedabeda. Adapun cara memilih kualitas mie sohun yang baik seperti yang tertulis di sajiansedap.com oleh anonim (2016) yaitu cara yang paling mudah untuk menilai mutu mie sohun adalah dengan menilai mutu sensoris atau mutu organoleptiknya. Paling tidak, ada 5 parameter sensoris utama yang perlu dinilai, yaitu penampakan atau karakteristik mie sohun yang cenderung transparan, sohun yang didiamkan beberapa saat setelah matang akan menjadi lengket dan akan menempel satu sama lain, warna mie sohun putih kusam transparan, bau khas pati tanpa bau zat kimia yang menyengat, rasanya yang cenderung tawar dan tekstur kuat \& liat saat masih kering serta licin dan mudah terputus saat matang.
Dengan hasil tersebut jika di bandingkan dengan SNI Sohun (SNI 01-3723-1995) bahwa standar mutu sohun seharusnya memiliki warna normal (putih kusam tansparan). Sehingga dari ke 5 sampel mie sohun yang diperiksa hanya 3 sampel yang aman dikonsumsi karena tidak terindikasi menggunakan klorin dan mendapatkan hasil pemeriksaan uji organoleptik dengan warna putih kusam transparan yaitu sohun sampel A, D, dan E. Sedangkan 2 sampel lainnya yaitu sohun sampel B dan sohun sampel C terindikasi menggunakan klorin karena mendapat hasil uji organoleptik dengan warna mie sohun putih mengkilap dan lebih bersih sehingga tidak aman untuk dikonsumsi karena dapat menimbulkan dampak gangguan kesehatan pada manusia. Penggunaan pewarna makanan dan minuman yang aman telah diatur oleh Pemerintah. Hal ini dibuat dengan tujuan agar bahan makanan yang beredar terutama pewarna makanan yang digunakan memenuhi persyaratan mutu kesehatan.

2. Hasil Pemeriksaan Kadar Klorin pada Mie Sohun yang dijual di Pasar Kemantran Kabupaten Tegal

\begin{tabular}{ccc}
\hline No & Kode Sampel & $\begin{array}{c}\text { Kadar } \\
\text { Klorin } \\
(\mathrm{mg} / \mathrm{L})\end{array}$ \\
\hline 1. & Sohun Sampel A & $(-)$ negatif \\
2. & Sohun Sampel B & 0,1 \\
3. & Sohun Sampel C & 0,2 \\
4. & Sohun Sampel D & $(-)$ negatif \\
5. & Sohun Sampel E & $(-)$ negatif
\end{tabular}

Pemeriksaan sampel mie sohun pada penelitian klorin yang dilakukan di Laboratorium Kesehatan Masyarakat Kabupaten Banyumas pada tanggal 02 Februari 2018, didapatkan hasil 2 sampel mie sohun positif menggunakan klorin yaitu sampel sohun B dengan kadar klorin 0,1 $\mathrm{mg} / \mathrm{L}$ dan sampel sohun $\mathrm{C}$ dengan kadar klorin 0,2 mg/L sedangkan 3 sampel lainnya yaitu sampel sohun A, sampel sohun D, dan sampel sohun E menujukkan hasil negatif adanya klorin.

Dari hasil diatas menunjukkan bahwa tidak semua mie sohun di Pasar Kemantran Kabupaten Tegal dalam proses pembuatannya menggunakan klorin sebagai pemutih. Maka dari itu warga masyarakat tidak perlu khawatir memperoleh mie sohun dengan kualitas yang buruk karena dari hasil penilitian menunjukkan 3 dari 5 sampel mie sohun yang di jual di Pasar Kemantran Kabupaten Tegal dengan distributor yang berbeda tidak menggunakan klorin dalam proses pembuatannya sehingga memliki kualitas yang baik dan aman di konsumsi oleh masyarakat. 
Makanan mempunyai peranan yang sangat penting dalam kesehatan masyarakat. Seluruh anggota masyarakat tanpa kecuali adalah konsumen makanan itu sendiri dan yang menentukan kualitas makanan baik, dapat ditinjau dari beberapa aspek, diantaranya aspek kelezatan, cita rasa, kandungan zat gizi dalam makanan dan aspek kualitas makanan, baik secara bakteriologis, kimia dan fisik harus selalu diperhatikanMakanan yang pada dasarnya telah mengandung zat berbahaya. Makanan tersebut tetap dikonsumsi manusia karena ketidaktahuan mereka, dapat dibagi menjadi 3 golongan. Salah satunya adalah makanan sebagai perantara jika suatu makanan yang terkontaminasi dikonsumsi oleh manusia, didalam tubuh manusia agent penyakit pada makanan itu memerlukan masa inkubasi untuk berkembang biak dan setelah beberapa hari dapat mengakibatkan munculnya gejala penyakit (Chandra, 2006).

Menurut Adiwisastra (1989) menyebutkan bahwa salah satu penggunaan Bahan Tambahan Makanan (BTM) yang dilarang adalah klorin $\left(\mathrm{Cl}_{2}\right)$. Klorin adalah bahan kimia yang biasanya digunakan sebagai desinfektan, pemutih kertas dan proses tekstil. Departemen Kesehatan RI berdasarkan Peraturan Menteri Kesehatan RI No.33/Menkes/Per/IX/2012 mendefinisikan bahan tambahan pangan seperti yang telah disusun oleh komisi Codex Alimentarius. Klorin tidak termasuk dalam daftar bahan tamabahan kimia yang diperbolehkan untuk digunakan pada makanan dan minuman.

Sehingga dari hasil yang didapatkan jika dibandingkan dengan Peraturan Menteri Kesehatan RI No.33/Menkes/Per/IX/2012 tentang Bahan Tambahan Pangan (BTP) yang didalamnya tidak menyatakan bahwa klorin termasuk Bahan Tambahan Pangan (BTP) Kimia yang diperbolehkan oleh pemerintah, dari pernyataan tersebut bisa dikatakan bahwa tidak boleh ada sisa klorin pada makanan jenis apapun. Dengan demikian dari ke 5 sampel yang diperiksa hanya 3 sampel yang aman di konsumsi yaitu sohun sampel A, sohun sampel D, dan sohun sampel D karena menunjukkan hasil negatif penggunaan klorin, sedangkan 2 sampel lainnya yang positif menggunakan klorin dengan kadar klorin sohun sampel B 0,1 mg/L dan sohun sampel C 0,2 mg/L yang jika disesuai kan dengan Peraturan Menteri Kesehatan RI No.33/Menkes/Per/IX/2012 yang didalamnya tidak menyatakan bahwa klorin termasuk Bahan Tambahan Pangan (BTP) klorin tidak termasuk dalam Bahan Tambahan Pangan (BTP) Kimia yang diperbolehkan oleh pemerintah maka sampel sohun B dan sampel sohun $\mathrm{C}$ tidak aman dikonsumsi karena bisa menyebabkan dampak gangguan kesehatan pada manusia.

Efek klorin pada makanan atau minuman dalam jangka pendek menyebabkan penyakit maag dan dalam jangka panjang mengakibatkan penyakit kanker hati dan ginjal (Wahyu Tilawati dkk, 2015). Klorin sangat potensial untuk terjadinya penyakit di kerongkongan, hidung dan tract respiratory (saluran kerongkongan di dekat paru-paru). Klorin juga dapat membahayakan sistem pemafasan terutama bagi anak-anak dan orang dewasa. Dalam wujud gas, klor merusak membran mukus dan dalam wujud cair dapat menghancurkan kulit. Tingkat klorida sering naik turun bersama dengan tingkat natrium. Ini karena natrium klorida, atau garam, adalah bagian utama dalam darah (U.S. Department Of Health And Human Services, 2007).

3. Deskripsi Tingkat Pengetahuan Pedagang Mie Sohun Di Pasar Kemantran Kabupaten Tegal

\begin{tabular}{|c|c|c|c|c|c|}
\hline $\begin{array}{l}\mathrm{N} \\
\mathrm{O}\end{array}$ & $\begin{array}{l}\text { Resp } \\
\text { onden }\end{array}$ & $\begin{array}{l}\mathrm{U} \\
\mathrm{m} \\
\mathrm{ur}\end{array}$ & $\begin{array}{c}\text { Jenis } \\
\text { Kela } \\
\text { min } \\
(\mathrm{L} / \mathrm{P})\end{array}$ & $\begin{array}{l}\text { Pendi } \\
\text { dikan }\end{array}$ & $\begin{array}{c}\text { Tingkat } \\
\text { Pengetahu } \\
\text { an }\end{array}$ \\
\hline 1. & $\begin{array}{l}\text { Resp } \\
\text { onden } \\
\text { A }\end{array}$ & 43 & $\mathrm{~L}$ & SD & $\begin{array}{c}\text { Baik } \\
(69 \%)\end{array}$ \\
\hline 2. & $\begin{array}{l}\text { Resp } \\
\text { onden } \\
\text { B }\end{array}$ & 50 & $\mathrm{P}$ & SD & $\begin{array}{c}\text { Kurang } \\
\text { Baik } \\
(46 \%)\end{array}$ \\
\hline 3. & $\begin{array}{l}\text { Resp } \\
\text { onden } \\
\text { C }\end{array}$ & 42 & $\mathrm{P}$ & SD & $\begin{array}{l}\text { Buruk } \\
(15 \%)\end{array}$ \\
\hline 4. & $\begin{array}{l}\text { Resp } \\
\text { onden } \\
\text { D }\end{array}$ & 37 & $\mathrm{~L}$ & SMA & $\begin{array}{l}\text { Buruk } \\
(38 \%)\end{array}$ \\
\hline 5. & $\begin{array}{l}\text { Resp } \\
\text { onden } \\
\text { E }\end{array}$ & 37 & $\mathrm{P}$ & SMA & $\begin{array}{l}\text { Buruk } \\
(15 \%)\end{array}$ \\
\hline
\end{tabular}

Tingkat pengetahuan pedagang merupakan salah satu dari faktor yang mempermudah untuk terjadinya perilaku seseorang. Responden pada penelitian ini adalah 5 pedagang mie sohun yang mie sohunnya dijadikan sampel oleh peneliti. Tingkat pengetahuan responden diukur dengan memberikan 13 pertanyaan melalui lembar kuesioner. Tingkat pengetahuan pedagang dibagi menjadi 4 kategori yaitu: baik apabila jumlah skor $66 \%-100 \%$, cukup baik apabila jumlah skor 56\%$65 \%$, kurang baik apabila jumlah skor $40 \%-55 \%$, dan buruk apabila jumlah skor $<40 \%$. Kriteria penilaian tingkat pengetahuan pedagang diukur menggunakan teori Suharsini Arikunto (1993).

Berdasarkan wawancara peneliti pada 5 pedagang mie sohun yang ada di Pasar Kemantran Kabupaten Tegal, didapatkan hasil responden A dengan jumlah skor $69 \%$ termasuk kategori baik, responden B dengan jumlah skor $46 \%$ termasuk kategori kurang baik, responden $\mathrm{C}$ dengan jumlah skor $15 \%$ termasuk kategori buruk, responden D dengan jumlah skor $38 \%$ termasuk kategori buruk 
dan responden E dengan jumlah skor $15 \%$ termasuk kategori buruk.

Dengan demikian apabila hasil tersebut di persentasekan didapatkan hasil tingkat pengetahuan pedagang mie sohun sebagai berikut: 1 pedagang (20\%) memiliki tingkat pengetahuan yang baik, 1 pedagang $(20 \%)$ memiliki tingkat pengetahuan yang kurang baik, dan 3 pedagang (60\%) memiliki tingkat pengetahuan yang buruk tentang penggunaan klorin sebagai bahan tambahan pangan.

Pada umumnya responden sudah berada di usia produktif yaitu 37-50 tahun yang seharusnya sudah memiliki tingkat kemampuan penerimaan pengetahuan yang baik dan dianggap sudah memiliki pengetahuan yang cukup, dan dapat membedakan antara perilaku baik dan perilaku yang tidak baik untuk dilakukan, meskipun dalam praktiknya tidak selalu dapat melakukan perilaku yang baik. Pengalaman yang dimiliki dapat menjadi sumber pengetahuan atau cara memperoleh kebenaran dalam hal ini tentang bahan tambahan makanan, kegunaaan klorin dan dampak penggunaan klorin pada makanan. Dipengaruhi juga dengan ketersediaan informasi dan pendidikan non formal yang masih sedikit diikuti oleh pedagang mie sohun. Pernyataan tersebut didukung Notoatmodjo (2003) yang menyatakan bahwa pengetahuan adalah hasil tahu dari manusia yang sekedar menjawab pertanyaan "what". Pengetahuan merupakan hasil tahu dan ini terjadi setelah orang melakukan pengindraan terhadap objek tertentu.

Perilaku menurut Notoatmodjo (2003) adalah apa yang dikerjakan organisme itu baik yang dapat diamati secara langsung atau secara tidak langsung. Perilaku memegang peran penting dalam penentuan status kesehatan hal sesuai dengan teori H.L Blum bahwa status kesehatan dipengaruhi oleh faktor lingkungan, perilaku, pelayanan kesehatan, dan genetik. Oleh karena itu keempat faktor tersebut harus mendapat perhatian yang serius dalam upaya pencapaian derajat kesehatan yang optimal. Meskipun perilaku merupakan rangsangan yang berasal dari luar, namun dalam memberikan respons sangat tergantung pada karakteristik dan faktor lain dari individu tersebut. Faktor yang membedakan respons terhadap stimulus (determinan perilaku) dapat dibagi menjadi 2: Determinan Internal karakteristik individu yang bersifat bawaan misal, tingkat kecerdasan, tingkat emosional, dan jenis kelamin. Determinan Eksternal meliputi faktor yang berasal dari lingkungan baik lingkungan fsik, sosial, budaya, ekonomi, dan politik. Faktor lingkungan sering disebut faktor yang paling dominan dalam mewarnai perilaku seseorang (Notoatmodjo, 2007).

\section{SIMPULAN DAN SARAN SIMPULAN}

1. Dari keseluruhan sampel mie sohun yang diteliti secara organoleptik, 2 dari 5 sampel mie sohun memiliki warna putih mengkilap yang artinya terindikasi menggunakan klorin yaitu sampel sohun B dan sampel sohun C.

2. Pemeriksaan kadar klorin pada sampel didapatkan hasil 2 sampel mie sohun positif menggunakan klorin yaitu sampel sohun B dengan kadar klorin $0,1 \mathrm{mg} / \mathrm{L}$ dan sampel sohun C dengan kadar klorin 0,2 mg/L sedangkan 3 sampel lainnya yaitu sampel sohun A, sampel sohun D, dan sampel sohun E menunjukkan hasil negatif menggunakan klorin.

3. Hasil penelitian menyatakan sebanyak 1 pedagang memiliki tingkat pengetahuan yang baik, 1 pedagang memiliki tingkat pengetahuan yang kurang baik, dan 3 pedagang memiliki tingkat pengetahuan yang buruk tentang penggunaan klorin sebagai bahan tambahan pangan.

\section{SARAN}

\section{Bagi Masyarakat}

Sebaiknya lebih berhati-hati dalam memilih bahan makanan terutama mie sohun dan masyarakat perlu mengetahui tentang ciri-ciri fisik mie sohun yang menggunakan klorin. Ciri-ciri fisik mie sohun yang menggunakan klorin yaitu memiliki warna putih mengkilap dan lebih bersih serta terdapat aroma pati yang tercampur dengan zat kimia yang menyengat.

\section{Bagi Pedagang}

Sebaiknya lebih selektif dan hati-hati ketika menerima mie sohun yang terindikasi penggunaan klorin dari distributor, dengan salah satu ciri-ciri nya adalah warna mie sohun lebih mengkilap dan lebih bersih dibanding mie sohun yang tidak menggunakan klorin yaitu putih kusam.

\section{Bagi Dinas Kesehatan}

a. Sebaiknya lebih memperketat pengawasan terhadap penggunaan Bahan Tambahan Pangan (BTP) khususnya pada industri-industri makanan.

b. Sebaiknya dilakukan pengarahan dan penyuluhan terhadap pedagang yang ada di Pasar Kemantran Kabupaten Tegal tentang Bahan Tambahan Pangan (BTP) yang di perbolehkan maupun tidak di perbolehkan oleh pemerintah. 


\section{DAFTAR PUSTAKA}

Abdi Gunawan. 2015. Pangan Indonesia yang Sehat dan Aman. https://www.kompasiana.com/ diakses pada tanggal 4 Januari 2018 pukul 02.00 WIB

Adwisastra A. 1989. Sumber, Bahaya, serta Penanggulangan Keracunan. Bandung: Angkasa

Anwar, dkk. 1998. Sanitasi Makanan dan Minuman Pada Institusi Pendidika Tenaga Sanitasi. Jakarta: Pusat Pendidikan Tenaga Kesehatan, Departemen Kesehatan RI

American Marketing Association. 1937. Journal of Marketing. Amerika Serikat: The American Marketing Association (AMA)

Badan Pengawas Obat dan Makanan RI Nomor. 37 tahun 2013

Budiman Chandra. 2006. Pengantar Kesehatan Lingkungn. Jakarta: EGC

Cahyo Saparinto dan Diana Hidayanti. 2006. Bahan Tambahan Pangan. Yogyakarta: Kanisius

Departemen Kesehatan RI. 2009. Rencana Pembangunan Jangka Panjang Bidang Kesehatan 2005-2025. Jakarta: Depkes RI

Direktorat Agroindustri BPPT. 1999. Laporan Akhir Proyek IPTEKDA. Jakarta: BPP Teknologi

Direktorat Kredit, BPR dan UMKM Bank Indonesia. 2007. Pola Pembiayaan Usaha Kecil Syariah (PPUK-Syariah) Industri Sohun. Jakarta: Bank Indonesia

Ditjen PPM dan PLP. 1990. Pengamatan Kontaminasi Makanan dan Prosedur Kerja Tetap Penanggulangan Keracunan Makanan. Jakarta: Kementrian kesehatan RI

Fitrah M,dkk. 2008. Sejarah Unsur Halogen. http://rumahkimia.wordpress.com diakses pada tanggal 4 januari 2018 pukul 01.39 WIB
Farah Tifani. 2013. Study Hygiene Sanitasi Makanan Industri Sohun PT. Naga Sakti Kecamatan Subang Kabupaten Banyumas Tahun 2013. Purwokerto: Politeknik Kesehatan Kementrian Kesehatan Semarang Prodi DIII Kesehatan Lingkungan Purwokerto

Leni Herliani Afrianti. 2010. Teknologi Pengawetan Makanan. Bandung: Alfabeta

Luthana, Y.K. 2008. Klorin atau $\mathrm{Ca}\left(\mathrm{OCl}_{2}\right)$. https://yongkikastanyaluthana.wordpress. com. Diakses pada tanggal 4 Januari 2018 pukul 02.19 WIB

MacDougal, J.A. 1994. Ekspose Pencemaran di Sumut.http://www.library.ohiou.edu diakses pada tanggal 4 Januari 2018 pukul 01.47 WIB

Miftahul Farid. 2015. Identifikasi Klorin Pada Beras Yang Dijual Di Pasar Kindali Limpuar Kecamatan Gambut. Banjarbaru: Politeknik Kesehatan Kementrian Kesehatan Banjarmasin

My Collage and I. 2014. Toksisitas Klorin DanCaraPenanganannya.http://nitamusti ka16.wordpress.com diakses pada tanggal 4 Januari 2018 pukul 02.50 WIB

Notoatmodjo, Soekidjo,2007. Promosi Kesehatan dan Ilmu Perilaku. Jakarta: Rineka Cipta

Parnomo, A. 2003. Pembuatan Cairan Pemutih. Jakarta: Puspa Swara

Peraturan Daerah Kota Bandung Nomor 2 Tahun 2009 tentang Penataan Pasar Tradisional, Pusat Perbelanjaan, dan Toko Modern

Peraturan Menteri Kesehatan RI Nomor 33 Tahun 2012 tentang Bahan Tambahan Pangan

Peraturan Pemerintah Nomor 28 Tahun 2004 tentang Keamanan, Muru, dan Gizi Pangan

Sajiansedap.com. 2016. Tips Sekilas Tentang Soun, Bihun, dan Misoa. Sajiansedap.grid.id/tips/sekilas-tentangsoun-bihun-dan-misoa diakses pada tangga; 4 Januari 2018 pukul 12.50 WIB 
Santi Novita dan Retno Adriyani. 2013. Tingkat Pengetahuan dan Sikap Pedagang Jajanan Tentang Pemakaian Natrium Siklamat dan Rhodamin B. Surabaya: Universitas Airlangga

SNI 01-3723-1995 tentang Sohun

Undang-Undang RI Nomor 23 Tahun 1992 tentang Kesehatan

Undang-Undang RI Nomor 18 Tahun 2012 tentang Pangan

U.S. Departement Of Health And Human Services. 2007. Clhorine. http://www.atsdr.cdc.gov diakses pada tanggal 4 Januari 2018 pukul $03.00 \mathrm{WIB}$
Wahyu Tilawati, dkk. 2015. Identifikasi dan Penetapan Kadar Klorin $\left(\mathrm{Cl}_{2}\right)$ Dalam Beras Putih di Pasar Tradisional Klepu dengan Metode Argentometri. Klaten: Sekolah Tinggi Ilmu Kesehatan Muhammadiyah Klaten

Wisnu Cahyadi. 2006. Analisis dan Aspek Kesehatan Bahan Tambahan Pangan. Jakarta: Bumi Aksara

Wisnu Cahyadi. 2008. Analisis dan Aspek Kesehatan Bahan Tambahan Pangan Edisi 2. Jakarta: Bumi Aksara 